Journal of Advanced College of Engineering and Management, Vol. 5, 2019

\title{
SUSTAINABLE ENERGY PLANNING FOR NEPAL IN THE FEDERAL STRUCTURE
}

\author{
Shailendra Bhusal ${ }^{1}$, Amrit Man Nakarmi ${ }^{2}$ \\ Email Address: shailendra.bhusal@gmail.com \\ ${ }^{2}$ Professor, Department of Mechanical Engineering, Institute of Engineering, Pulchowk Campus, T.U.
}

\begin{abstract}
This paper examined the energy planning in each province, sustainable technology policy interventions in the energy demand and social cost benefit analysis in energy sector for Nepal in the federal structure over the period $2017-2050$ using LEAP-IBC modelling framework.Four scenarios were developed, reference, Low economy, accelerated economy and sustainable scenario, former three are based on socioeconomic assumption and later is technology intervention case. In reference scenario, energy consumption will increase by 3 folds from 544 PJ to 1645 PJ during 2017-2050, whereas in sustainable scenario the value expected to increase to 866 PJ by 2050.In the base year 2017, emission is 69 million metric tons of $\mathrm{Co} 2$ equivalents whereas per capita emission is 2.36 metric tons. In the reference scenario the carbon emission increases to 178 million Metric tons of $\mathrm{CO}_{2}$ equivalent in 2050 whereas per capita carbon emission increases to the 4.06 metric ton in the year 2050. In sustainable scenario the carbon emission increases to 21.95 million Metric tons of $\mathrm{CO}_{2}$ equivalent in 2030 whereas per capita carbon emission reduces to the 0.64 metric ton in the year 2030 due to the technological policy intervention. The calculated NPV shows that SED scenario is most economically viable with NPV value 7899 million NRS.In sustainable policy scenario efficient as well as new and improved technologies has been considered as a result of which substantial amount of reduction in energy intensities and per capita final energy consumption is achieved. In reference scenarioper capita energy consumption $18 \mathrm{GJ}$ is increase to $40 \mathrm{GJ}$ and in sustainable scenario is expected to 19 GJ by 2050 .
\end{abstract}

Keywords: Energy Planning; LEAP-IBC; Emission

\section{Introduction}

Energy is a crucial element for sustainable development of country. Unless the energy sector is geared up for efficient, secure and indigenous sustainable resources, the economy cannot move forward on higher growth path. Access to reliable and affordable energy services has become fundamental in reducing poverty, increasing productivity, enhancing competitiveness and promoting economic growth. Sustainable energy planning and management is a method of research, development and promotion of rationality in planning and policy making that optimizes the benefits for global as well as local societies by making use of cost-effective energy technologies and clever policy strategies.

Table 1: Energy balance of Nepal for base year 2017 in TJ[1],[5],[6],[8],[9],[10],[11],[18][19]

\begin{tabular}{|c|c|c|c|c|c|c|c|}
\hline \multicolumn{8}{|c|}{ Base Year (2017) Energy Balance (TJ) } \\
\hline Particulars & Petroleum Products & Coal & Hydro & Electricity & Biomass & $\begin{array}{c}\text { Modern } \\
\text { Renewabl } \\
\text { es }\end{array}$ & Total \\
\hline \multicolumn{8}{|c|}{ Primary Supply } \\
\hline $\begin{array}{l}\text { Indigenous } \\
\text { production }\end{array}$ & - & - & 18371 & - & 391532 & 17159 & 427062 \\
\hline Imports & 81464 & 38836 & - & 7830 & - & - & 128130 \\
\hline
\end{tabular}




\begin{tabular}{|c|c|c|c|c|c|c|c|}
\hline Exports & - & - & - & (10) & - & - & (10) \\
\hline Stock changes & $(964)$ & - & - & - & - & - & $(964)$ \\
\hline $\begin{array}{l}\text { Total Primary } \\
\text { Supply }\end{array}$ & 80,500 & 38,836 & 18,371 & 7,820 & 391,532 & 17,159 & 554,218 \\
\hline \multicolumn{8}{|l|}{ Transformation } \\
\hline Inputs & (1434) & - & - & - & - & - & (1434) \\
\hline $\begin{array}{l}\text { Electricity } \\
\text { generation }\end{array}$ & - & - & 14,697 & 15200 & - & - & 439 \\
\hline $\mathrm{T} \& \mathrm{D}$ losses & - & - & - & $(4,763)$ & - & - & $(3,078)$ \\
\hline $\begin{array}{l}\text { Other losses, } \\
\text { own-use etc. }\end{array}$ & - & - & & & - & - & $(3,200)$ \\
\hline $\begin{array}{l}\text { Net supply to } \\
\text { consumers }\end{array}$ & 79,066 & 38836 & 0 & 18,257 & 391532 & 17,159 & 544850 \\
\hline \multicolumn{8}{|l|}{ Final Consumption } \\
\hline Industry & 737 & 35,938 & 0 & 6,442 & 9,417 & - & 52,534 \\
\hline Residential & 9533 & 93 & & 9127 & 372592 & 17,159 & 407,939 \\
\hline Commercial & 4930 & 2804 & & 2,254 & 9,524 & - & 19512 \\
\hline Transport & 56021 & - & & 24 & - & - & 56045 \\
\hline Agriculture & 7,846 & - & & 407 & - & - & 8,253 \\
\hline Total & 79067 & 38835 & 0 & 18254 & 391,533 & 17,159 & 544,848 \\
\hline Statistical error & 1 & (1) & - & (3) & (0) & - & \\
\hline
\end{tabular}

The main energy resource base in the Nepal are fuel wood, hydropower, petroleum products and other fuels like crop residues, livestock manure, biogas technology, micro- hydro turbines, coal, solar energy and wind energy etc. The resources are scarce and demand is increasing. The petroleum products supply is interrupted time to time so for the sustainability there is the need of the Sustainable Energy Planning and Management. The population and the GDP of the Nepal are increasing which forces the increase in the life standard and energy demand. To meet the high energy demand with the scarce available sources, there arises the policy problem and management problem. So to meet this scenario we need the energy planning.

\section{Literature Review}

Nepal is divided in three ecological region Himalayan, Hill and Terai. Before reconstruction of province Nepal is divided into 5 development regions and 75 districts. Eastern development region (EDR) contain 16 districts, Central development region (CDR) contain 19 districts, western development region (WDR) contain 16 districts, mid-western development region (MWDR) contains 
15 and far western development region contains 9 districts [2]. The energy balance is disaggregated using disaggregation ratio according to WECS energy demand survey 2011/12 [22][23]. Energy data were depicted in WECS survey report by development and ecological region. So energy in each province calculated accordance with below table:

Table 2: Relation between province, district and development region

\begin{tabular}{|l|l|}
\hline Description & Relation between province ,district and development region \\
\hline Province1 & Province 1=EDR-Saptari-siraha \\
\hline Province2 & Province $2=$ CDR Terai+saptari+siraha-Chitwan \\
\hline Province3 & Province 3= CDRHill +CDR Mountain+Chitwan \\
\hline Province4 & Province 4=WDR Hill+WDR Mountain-Arghakhanchi-Gulmi-palpa \\
\hline Province5 & $\begin{array}{l}\text { Province5=MWDR Hill+MWDRTerai +WDR } \\
\text { Terai+Arghakhanchi+Gulmi+palpa-Surkhet- salyan }\end{array}$ \\
\hline Province6 & Province6=MWDR mountain + Surkhet+ Salyan \\
\hline Province7 & PROVINCE 7=FWDR \\
\hline
\end{tabular}

Seven districts Saptari, Siraha, Chitwan, Arghakhanchi, Gulmi „Palpa ,surkhet ,Salyan energy consumption calculated with respect to proportion of Population and GDP.

\section{Energy Consumption in Each Province:}

Seven provinces are reconstructed on the basis of demographical, ecological and political structures such as population, geographical area, the human development Index, per capita income, agriculture production, roads, revenues, etc. On the basis of agriculture and other variables Province 3 comes out on top, Province 2 comes in second. Table 3 illustrates energy consumption by different economic sectors in each province. Total energy consumption in Nepal is 544.28PJ.The energy consumption in province 3 is $131.56 \mathrm{PJ}$ which is higher than other provinces. Province 2 contain most of industry and only Terai districts so energy consumption is higher than other Provinces one, four, five, six, seven. The consumption of energy in Province six is $16.53 \mathrm{PJ}$ which is lowest energy consumption than other provinces.

Table 3: Sectorial energy consumption in provinces fiscal year (2016/17) [1], [3],[18],[19]

\begin{tabular}{|c|c|c|c|c|c|c|}
\hline \multicolumn{7}{|c|}{ Energy consumption (PJ) } \\
\hline Province & Residential & Commercial & Transportation & Industrial & Agricultural & Total \\
\hline Prov.1 & 72.66 & 2.30 & 5.41 & 6.33 & 1.21 & 87.90 \\
\hline Prov.2 & 80.98 & 3.93 & 12.24 & 15.24 & 2.92 & 115.30 \\
\hline Prov.3 & 75.95 & 7.48 & 27.54 & 19.79 & 0.80 & 131.56 \\
\hline
\end{tabular}




\begin{tabular}{|c|c|c|c|c|c|c|} 
Prov.4 & 31.55 & 1.51 & 2.50 & 1.27 & 0.19 & 37.03 \\
\hline Prov.5 & 85.97 & 2.98 & 6.53 & 8.61 & 2.43 & 106.53 \\
\hline Prov.6 & 15.81 & 0.32 & 0.23 & 0.14 & 0.04 & 16.53 \\
\hline Prov.7 & 45.02 & 0.98 & 1.59 & 1.16 & 0.67 & 49.41 \\
\hline Total & 407.94 & 19.51 & 56.04 & 52.53 & 8.25 & 544.28 \\
\hline
\end{tabular}

\section{LEAP Energy Modelling Framework}

LEAP (Long-range Energy Alternatives Planning System) was originally created in 1980 for the Beijer Institute's Kenya Fuel wood Project, to provide a flexible tool for long-range integrated energy planning. LEAP provided a platform for structuring data, creating energy balances, projecting demand and supply scenarios, and evaluating alternative policies, the same basic goals as the current version of LEAP [13].LEAP follows an end use, demand driven approach, which means that the analysis starts from the end use of energy. Because LEAP is a very general purpose software tool, which can be used to build a wide variety of different models of energy systems, it is impossible to definitively describe its data requirements.

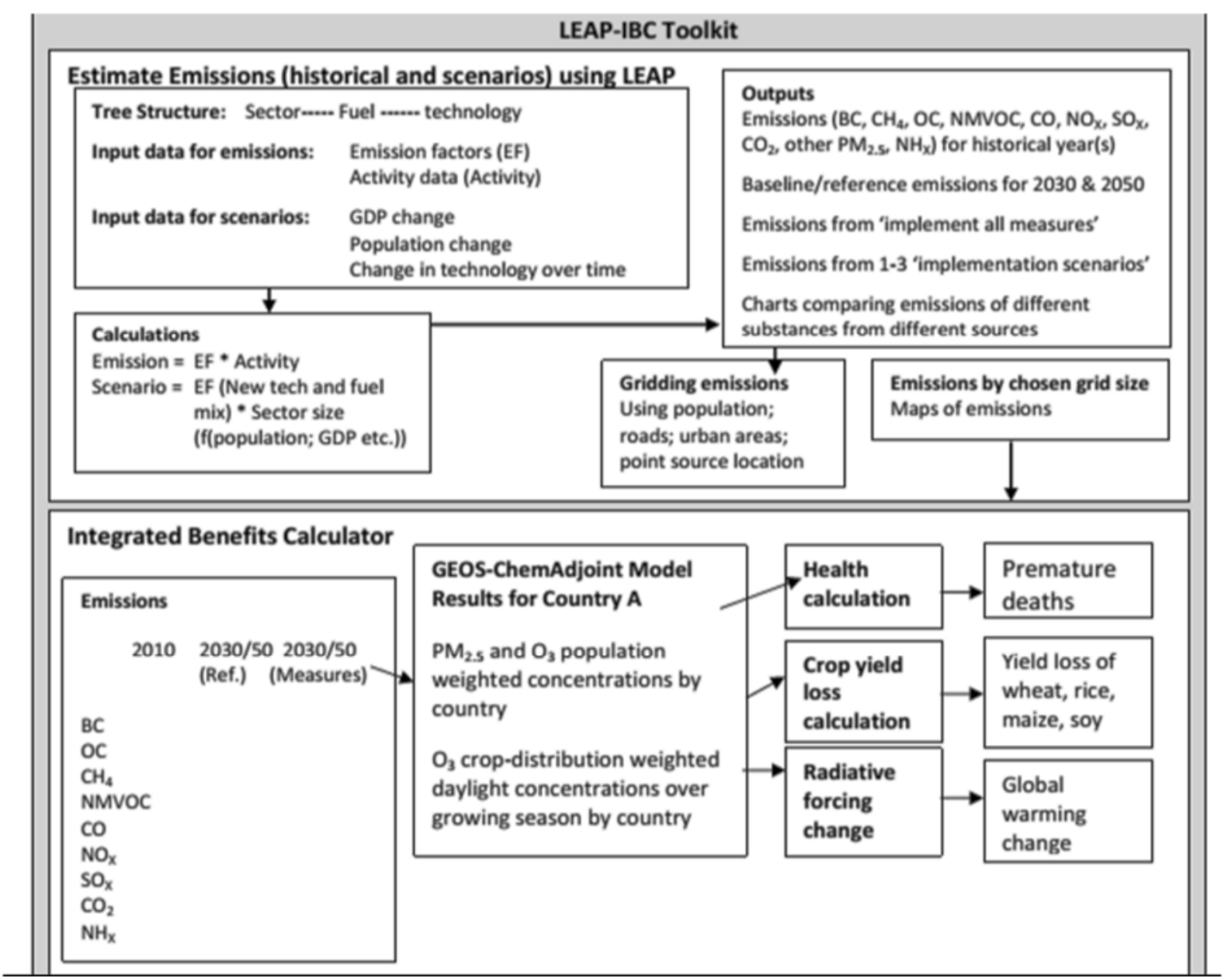

Fig1: LEAP-IBC modelling framework 
(Zhao, Liu, \& Zhao, 2011)Provides an important reference for the Chinese government to develop low-carbon economy using LEAP model. Four critical factors, the per capita GDP, energy consumption, energy structure, and $\mathrm{CO} 2$ emissions, are mainly considered as the indicators to measure the level of low-carbon economic development [21].

(Shakya, Kumar, \& Shrestha, 2012)Analyses the co-benefits of introducing a time variant carbon (C) tax scheme in Nepal, a hydropower resourceful country, by using a bottom up integrated energy system model based on the MARKetALlocation (MARKAL) framework with time horizon of 20052050 [26].

(Parajuli, Østergaard, Dalgaard, \& Pokharel, 2014) Assess the future primary energy consumption of Nepal, and the projection is carried out along with the formulation of simple linear logarithmic energy consumption models [12].

(Shakya, 2012)Studies the economy-wide consequences of introducing different levels of electrified mass transport systems in Nepal on the long term basis [14].(Shakya \& Shrestha, 2011) analyses the co-benefits of transport sector electrification in terms of reductions of greenhouse gas and local environmental emissions, improvement in energy security and employment generation during 20152050 in the case of Nepal - a developing country with large hydropower potential. A bottom up energy system model of Nepal based on the MARKAL framework was developed to assess the effects of meeting a part of the land transport service demand through electrified mass transport system and electric vehicles [15].

(Lund, 2007)Discusses the perspective of renewable energy (wind, solar, wave and biomass) in the making of strategies for a sustainable development using Energy Plan modelling framework [4].

(Nakarmi, Mishra, \& Banerjee, 2014) employs an integrated model for analysis of energy demand and MARKAl Allocation modelling framework for assessing different pathways for the development of energy systems of Nepal and this is the first attempt to integrate the MAED energy demand model with the MARKAL supply model for assessing and analysing energy systems and their implications in Nepal [7].

(Shrestha \& Rajbhandari, 2010)analyses the sectorial energy consumption pattern and emissions of $\mathrm{CO}_{2}$ and local air pollutants in the Kathmandu Valley, Nepal. It also discusses the evolution of energy service demands, structure of energy supply system and emissions from various sectors under the base case scenario during 2005-2050 [17].

\section{Methodology}

\section{Modelling Framework and Data input}

Out of the different energy modeling tools the LEAP modeling framework is being picked up for this thesis work due to its compatibility with published energy demand data. The Long-range Energy Alternatives Planning system (LEAP) is a widely-used software tool for energy policy analysis and climate change mitigation assessment developed at the Stockholm Environment Institute (SEI). It has been adopted by hundreds of organizations in more than 150 countries worldwide. 


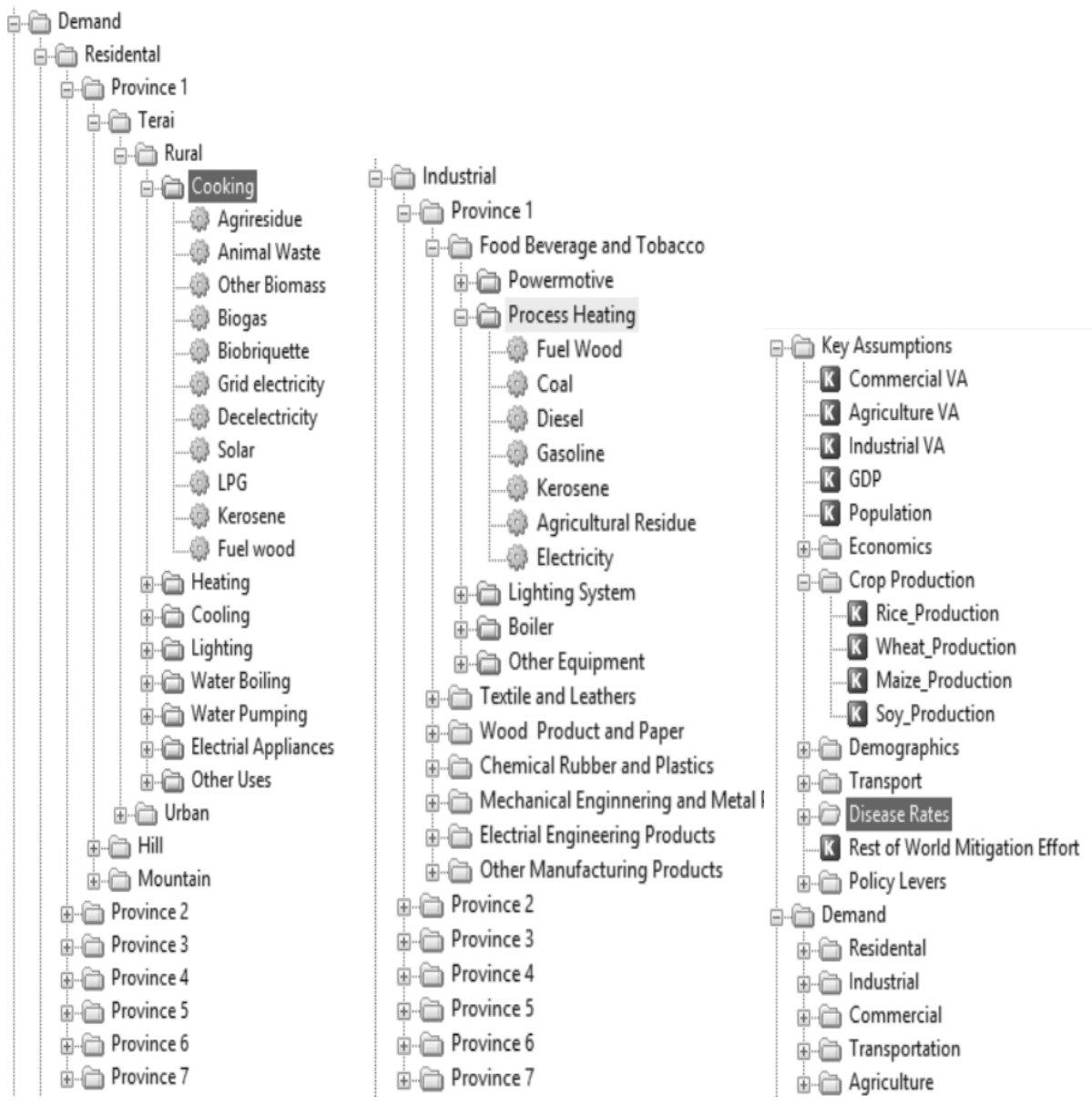

Fig 4: Key assumption, and disaggregation of residential and industrial sector.

The final energy demands of each economic sector are obtained from the prepared energy balance of base year 2017. Then each sector are disaggregated into the different development region, each development region is disaggregated into different physical region. For residential sector each physical region is disaggregated into rural and urban and is further disaggregated to end-use service demand. Similarly in the other economic sector each physical region is disaggregated into end-use service demand. According to the disaggregation branching was developed in the LEAP model as in the figure. 

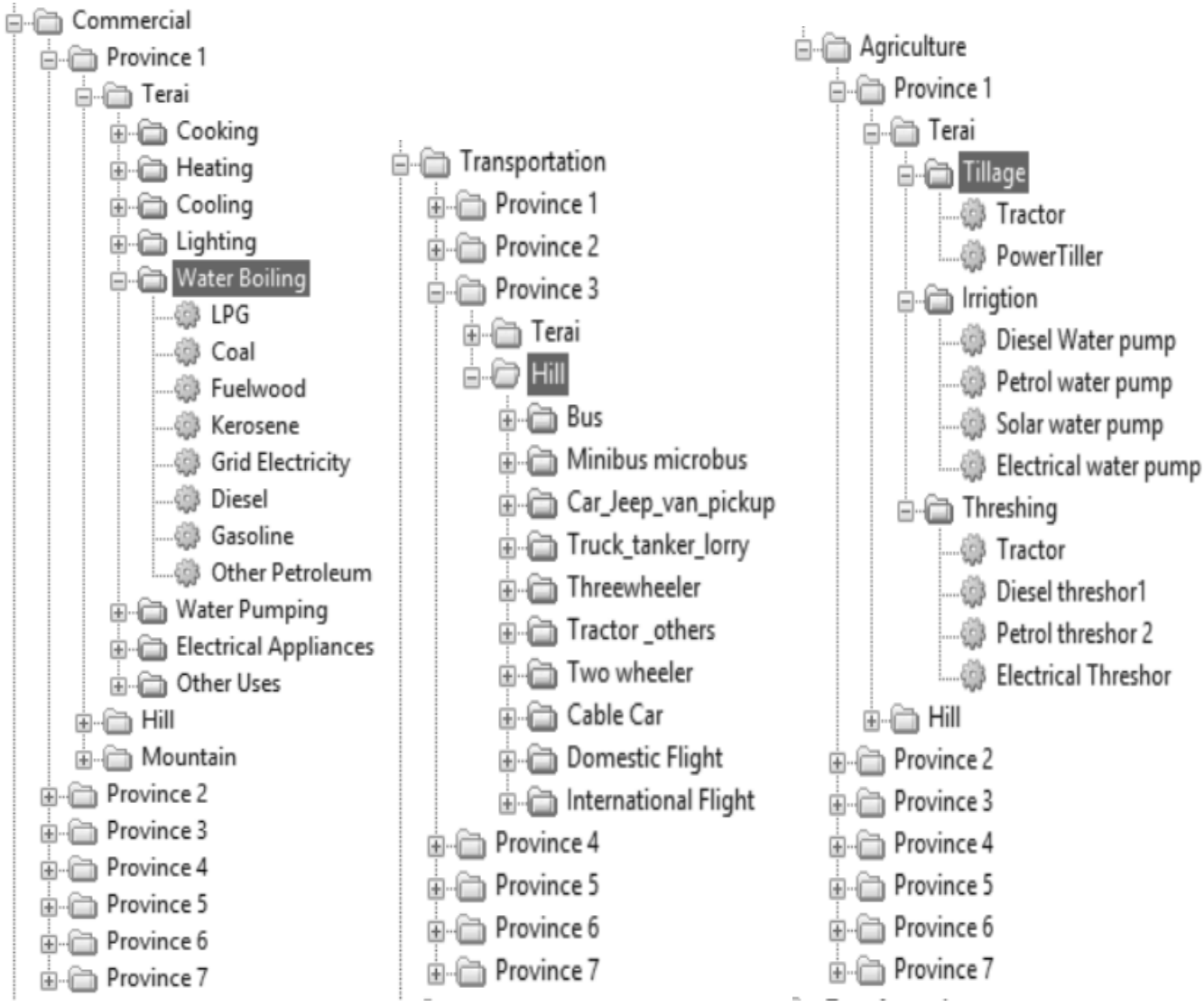

Fig 5: Key assumption, and disaggregation of Commercial, Transportation, and Agricultural sector.

\section{Elasticity Calculations}

The historical data of sectorial energy consumption, GDP, industrial VA, Commercial VA, and Agricultural VA are collected and different log linear regression models are developed to find the elasticity's for sectorial energy consumption.

The regression model is developed between following variables;

\begin{tabular}{|c|c|}
\hline Dependent Variable & Independent Variable \\
\hline Residential Energy Consumption (Y1) & Total Population (P1) \\
\hline Industrial Energy Consumption (Y2) & Industrial VA (X2) \\
\hline Commercial Energy Consumption (Y3) & Commercial VA (X3) \\
\hline Transportation Energy Consumption (Y4) & Total GDP (X4) \\
\hline Agricultural Energy consumption (Y5) & Agricultural VA (X5) \\
\hline
\end{tabular}

And the following results are obtained from the regression analysis. 
Table 4: Results from regression analysis

\begin{tabular}{|l|l|l|l|l|}
\hline Variables & R square & t value & P value & Elasticity \\
\hline $\log (\mathrm{Y} 1) \& \log (\mathrm{P} 1)$ & 0.588 & 4.14 & 0.00137 & 1.250 \\
\hline $\log (\mathrm{Y} 2) \& \log (\mathrm{X} 2)$ & 0.444 & 3.09 & 0.00928 & 0.944 \\
\hline $\log (\mathrm{Y} 3) \& \log (\mathrm{X} 3)$ & 0.122 & 2.29 & 0.22050 & 1.064 \\
\hline $\log (\mathrm{Y} 4) \& \log (\mathrm{X} 4)$ & 0.526 & 3.65 & 0.00335 & 0.818 \\
\hline $\log (\mathrm{Y} 5) \& \log (\mathrm{X} 5)$ & 0.742 & 5.88 & 0.00007 & 1.070 \\
\hline
\end{tabular}

The model validity needs t-value grater or equal to 2.25 and corresponding $p$-value must be less than $5 \%$. According to that, Five models are accepted.

\section{Demand Forecasting}

LEAP model uses the econometric method to forecast the energy demand of the country on the basis of base year calibrated data input in the model.

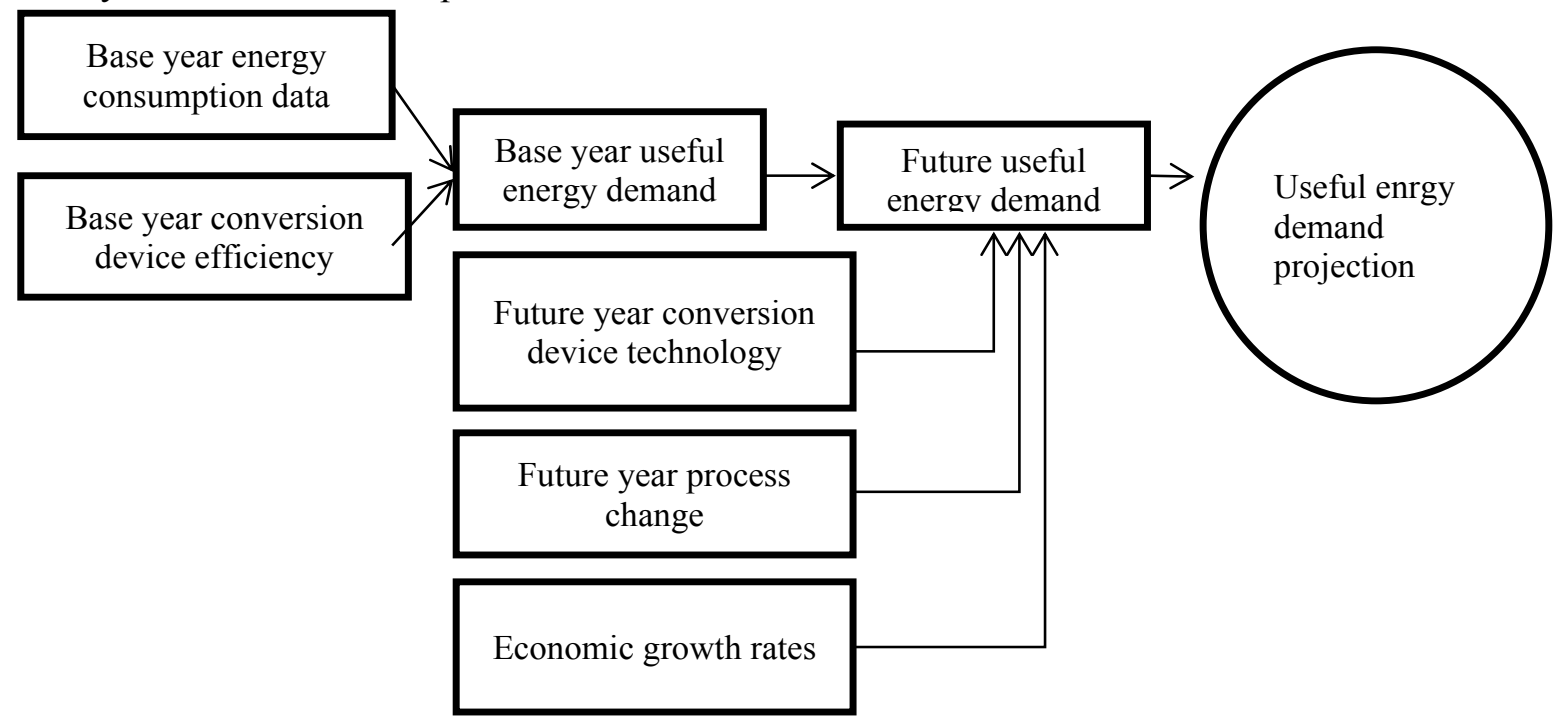

Figure 6: Energy demand projection flow chart

\section{Scenario Development}

Along with the REF scenario with other scenarios will be developed which helps in sustainable energy planning in each province.

\section{Low Economic Growth Scenario}

This scenario assumes a past 10 years average GDP growth rate of $4.5 \%$ relative to the $7 \%$ GDP growth rate assumed in the reference scenario. All other underlying assumptions with respect resource availability, technology and other parameters are similar to those in the reference year.

\section{High Economic Growth Scenario}

This scenario assumes that high GDP growth rate according to high developing countries GDP growth rate $9.2 \%$.It further assumes that the share of each demand technology in the energy supply in future years will be the same as in the reference year. 


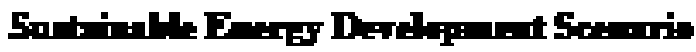

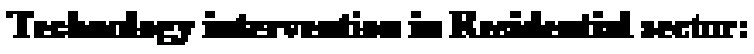

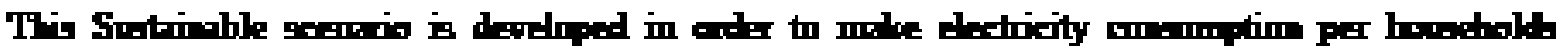

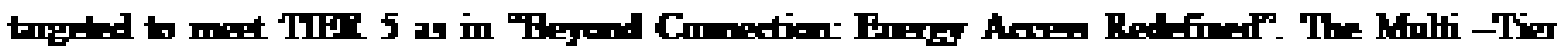
Mitrix fill electricity concmuption is d-pided fnllowing thle

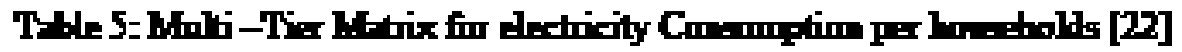

\begin{tabular}{|c|c|c|c|c|c|c|}
\hline & TIFet & TIExI & TIERE & TIËR3 & TII:4 & TIझ:s \\
\hline 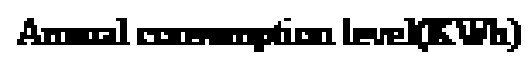 & 44.5 & 345 & 373 & 3365 & 31250 & 39000 \\
\hline 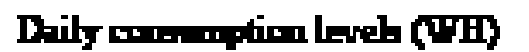 & cl2 & 312 & 3200 & 31000 & $33 \mathbf{4 2 5}$ & 30219 \\
\hline
\end{tabular}

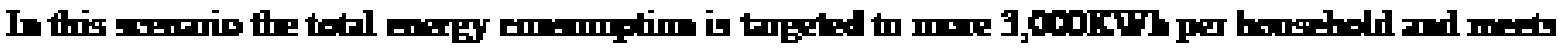

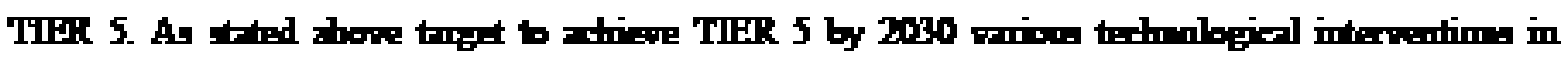

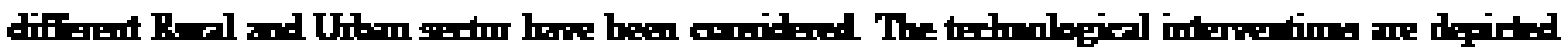
betw the

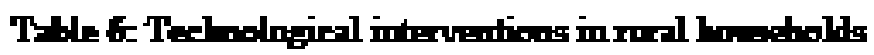

\begin{tabular}{|c|c|}
\hline E- & Darriptinen \\
\hline Couling & 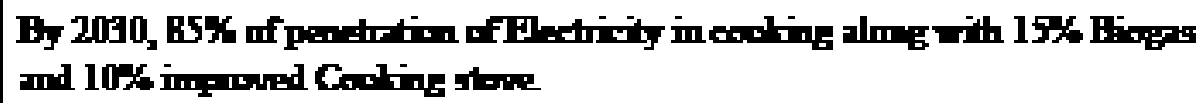 \\
\hline Hexting & 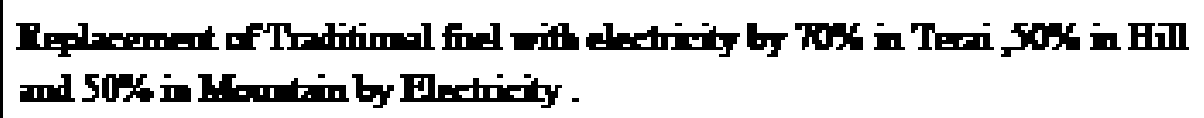 \\
\hline Conline & 100\% electricity aroes by 2030 . \\
\hline Liefing & $100 \%$ eletricity aneeg by 2030. \\
\hline Wats Bniling & 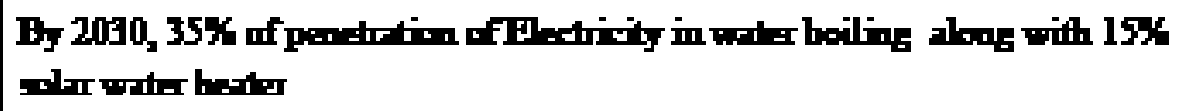 \\
\hline $\begin{array}{l}\text { Electrical } \\
\text { Applianse }\end{array}$ & $100 \%$ elextricity aneeg by 2030. \\
\hline
\end{tabular}

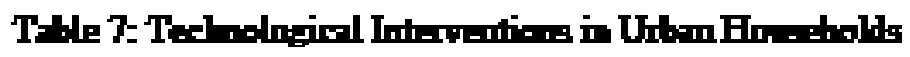

\begin{tabular}{|c|c|}
\hline E-1 & Denrritiven \\
\hline Couling & J00\% of pecetraim of El extririty by 2030 \\
\hline Herting & J00\% of pe- Etraim of El extririty by 2030 \\
\hline Conling & J00\% elatrinity arres by 2030 . \\
\hline Liefing & J00\% eletririty arreg by 2030 \\
\hline
\end{tabular}




\begin{tabular}{|c|c|}
\hline Whar Bnimg & 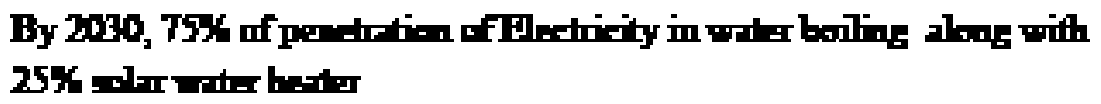 \\
\hline Electrizal Applime & l00\% elestririty arrea by 2030 . \\
\hline
\end{tabular}

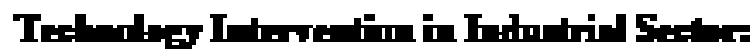

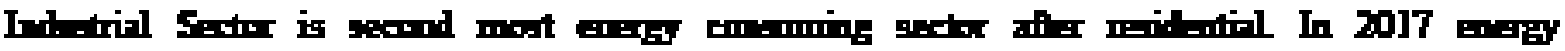

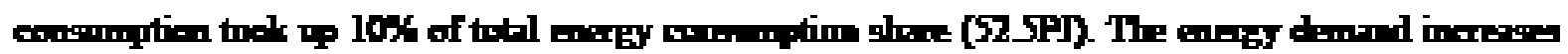

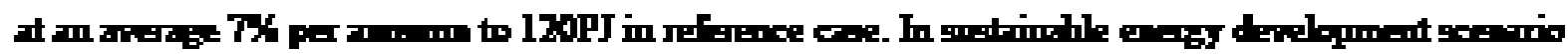
the mojor intevention toke whith ant dipicted belme toble

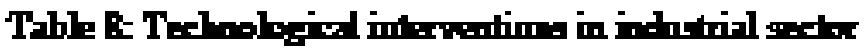

\begin{tabular}{|c|c|}
\hline E-1 Une & Dearipting \\
\hline Puing Mative & 100x of pes-drtien of Electricity by 2030 \\
\hline $\begin{array}{l}\text { Frocies } \\
\text { Hextings }\end{array}$ & 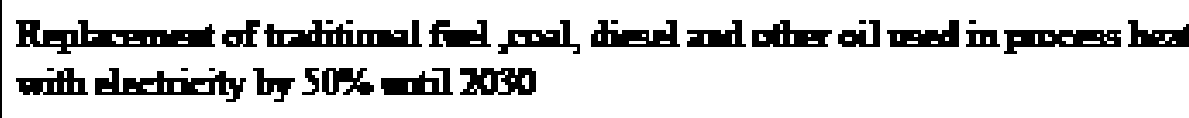 \\
\hline Boiln & 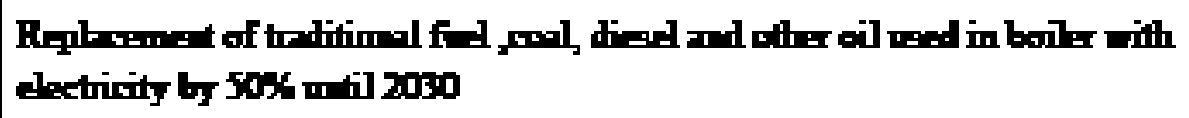 \\
\hline Liejing & 100X uf perdetion of Electricity by 2030 \\
\hline $\begin{array}{l}\text { Othe } \\
\text { Equiment }\end{array}$ & 100x of pea dertien of Electricity by 2030 \\
\hline
\end{tabular}

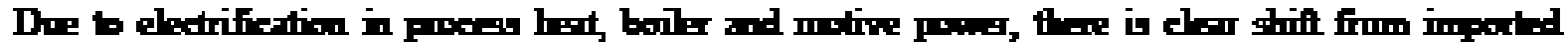

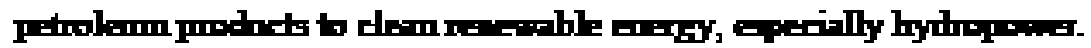

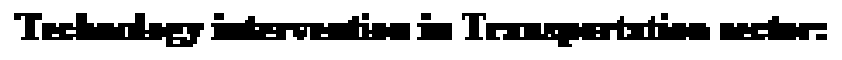

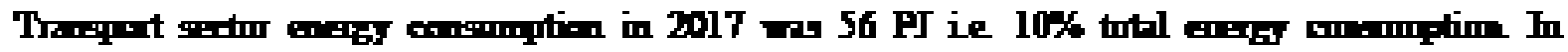

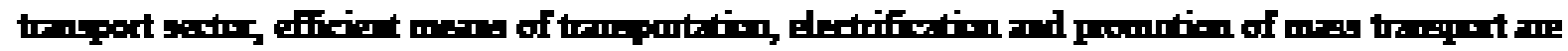

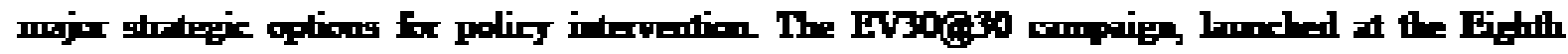

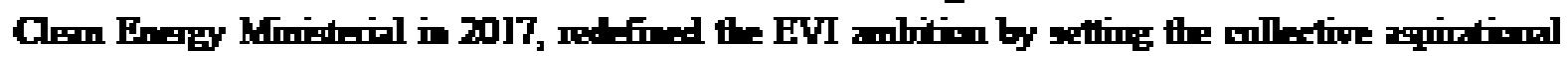

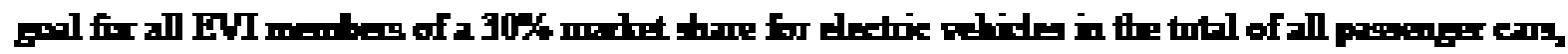

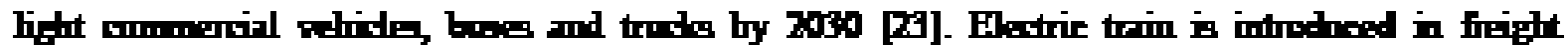

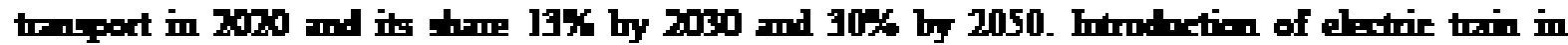

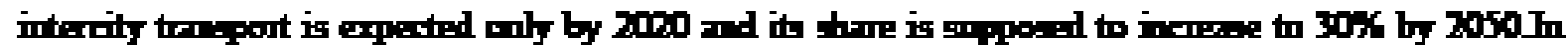

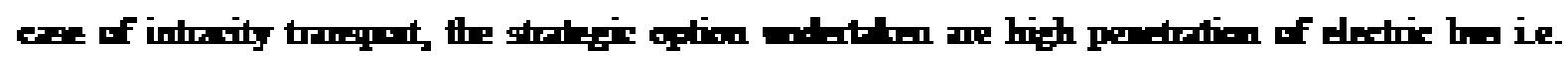

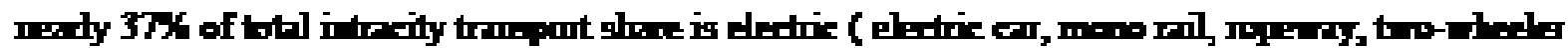

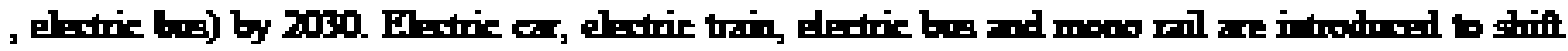

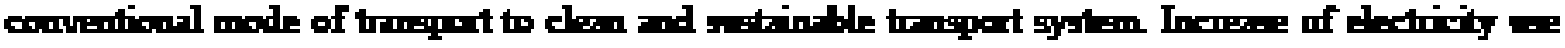

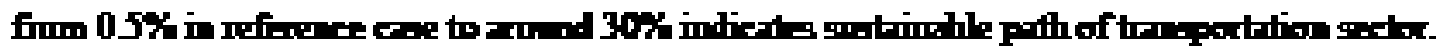

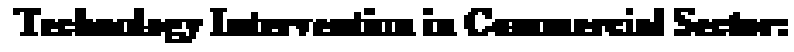

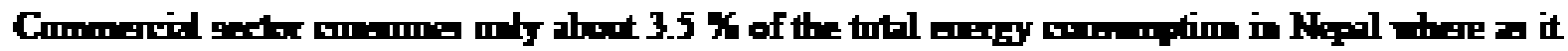

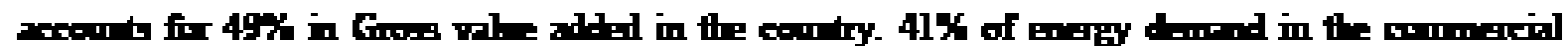




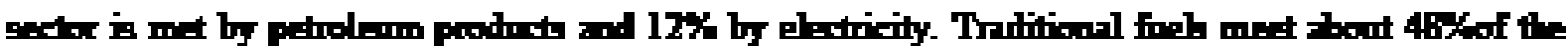

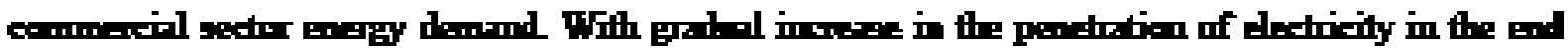

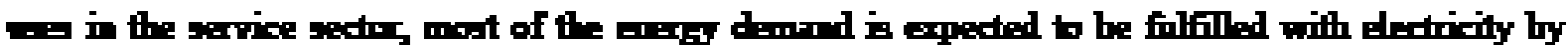

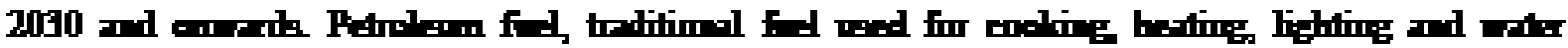
hexims rploned with electricity by 2030.

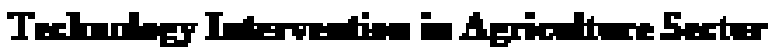

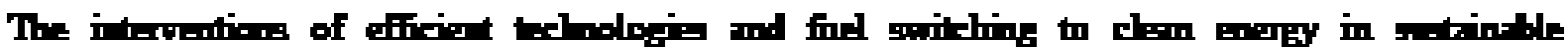

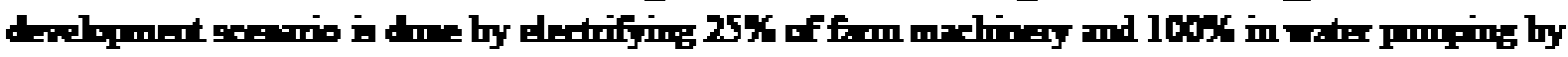

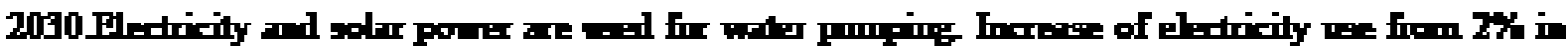

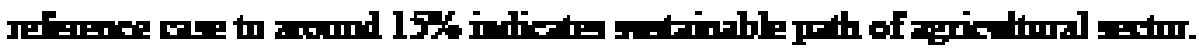

\section{Remlt and Doncrim}

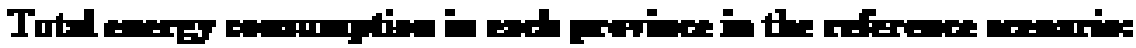

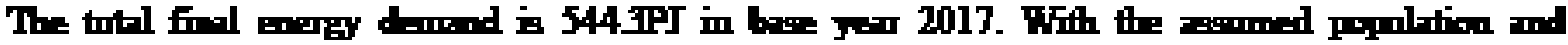

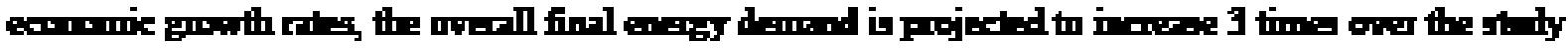

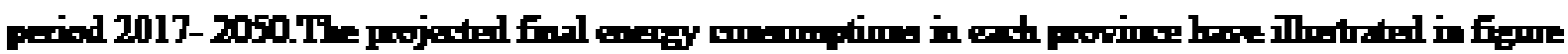
belme.

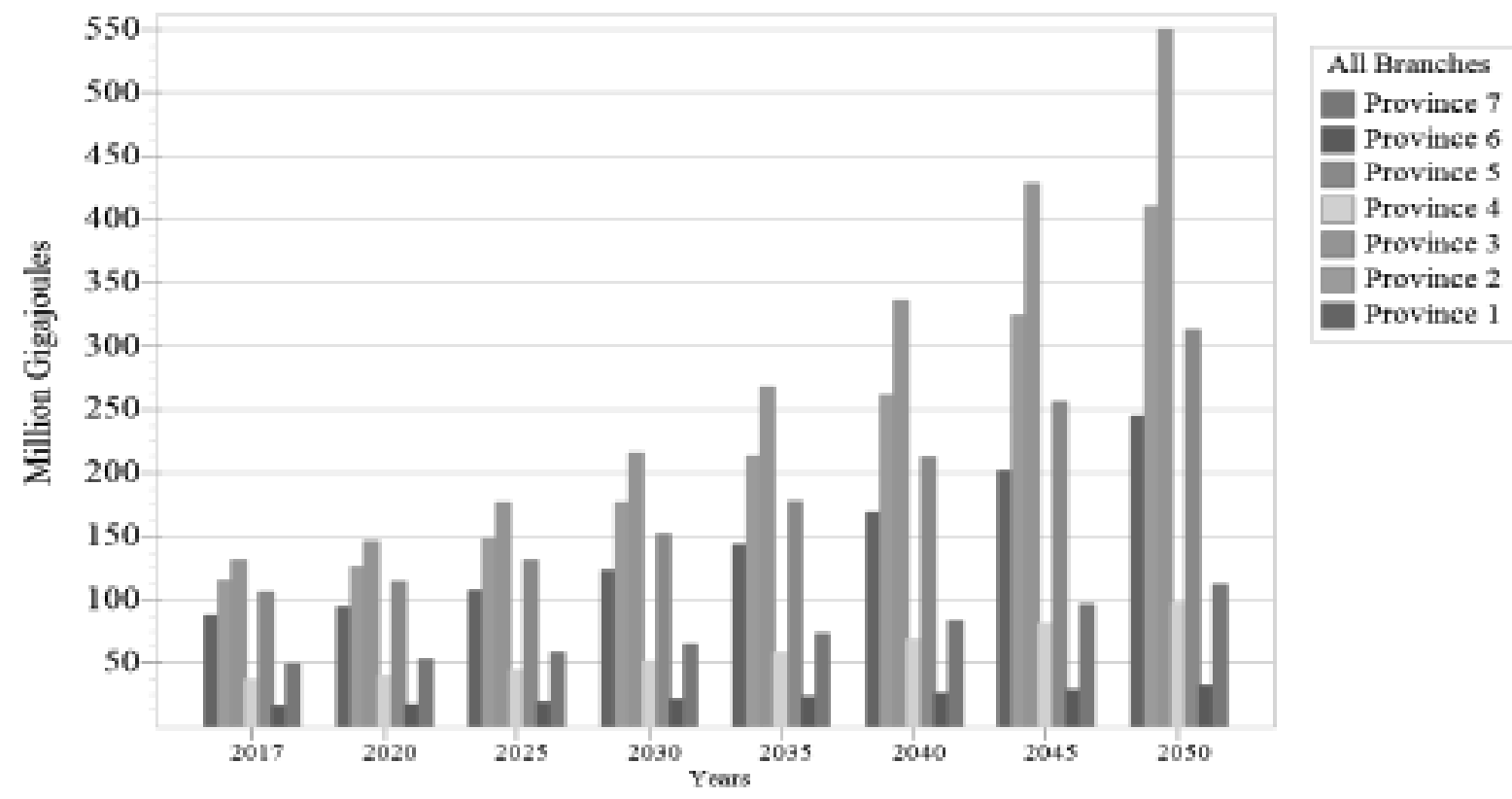

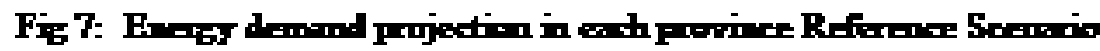

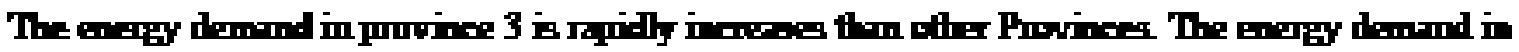

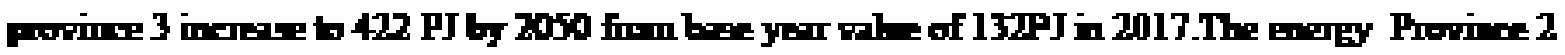

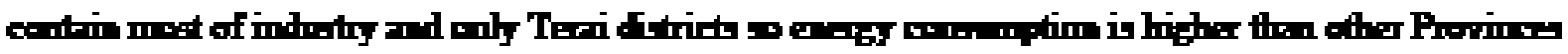

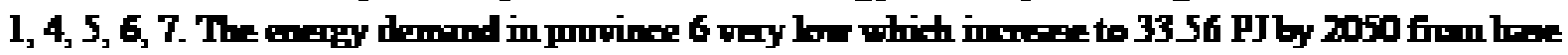
yex prlne of $16.5 \mathrm{PJ}$ in $\mathrm{X} 17$.

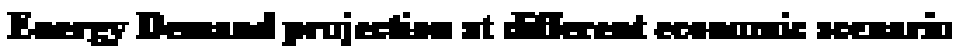

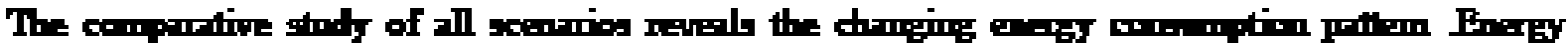

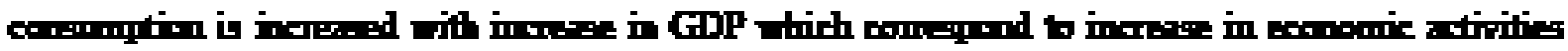




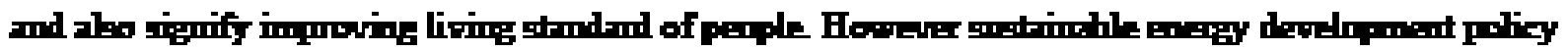

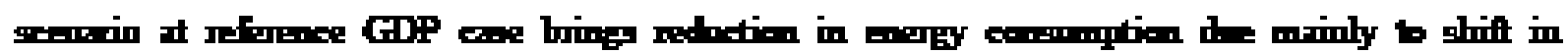

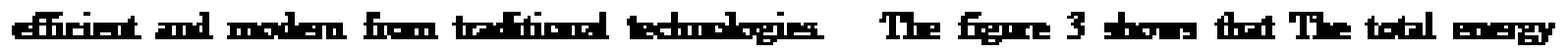

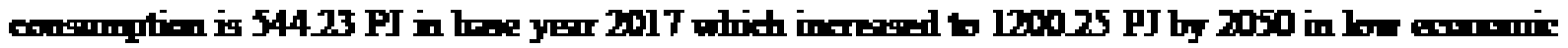

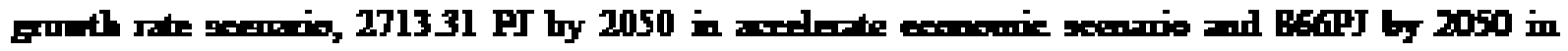

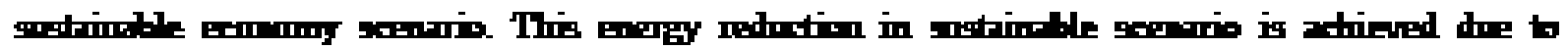

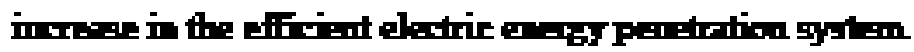

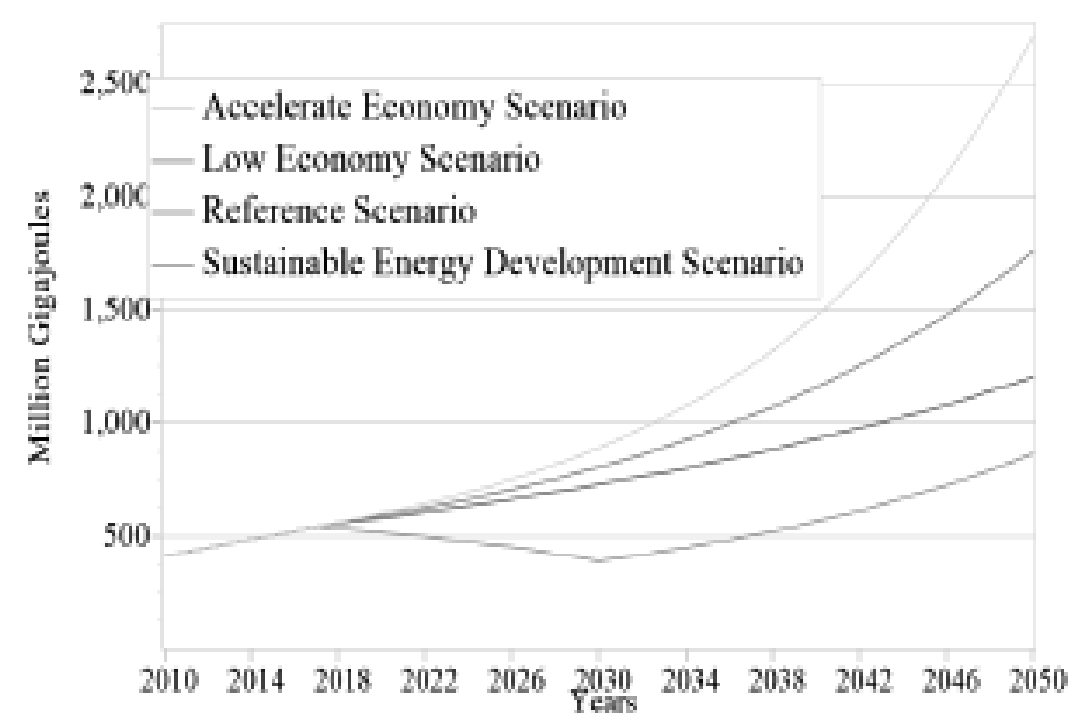

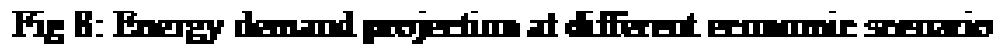

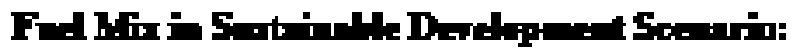

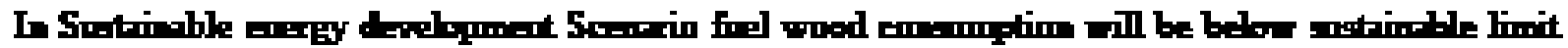

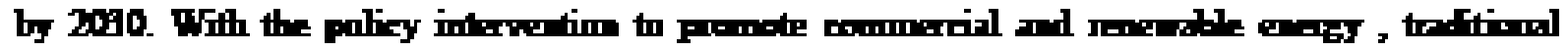

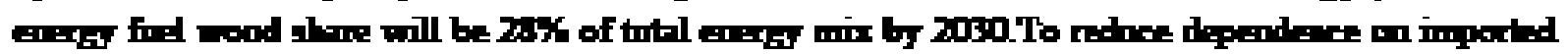

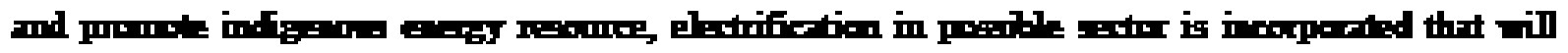

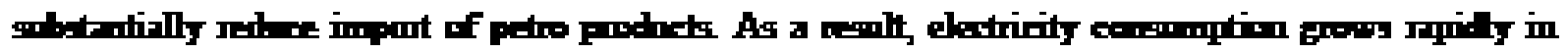

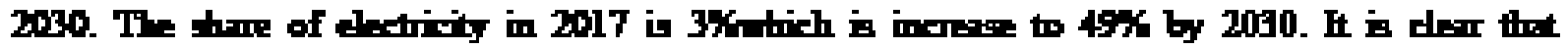

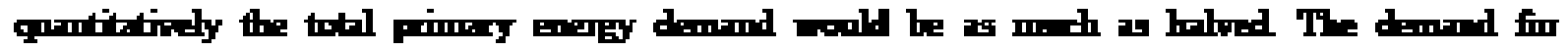

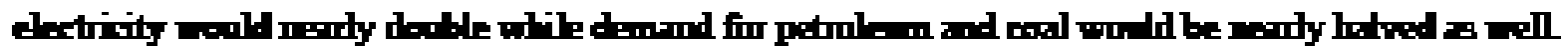




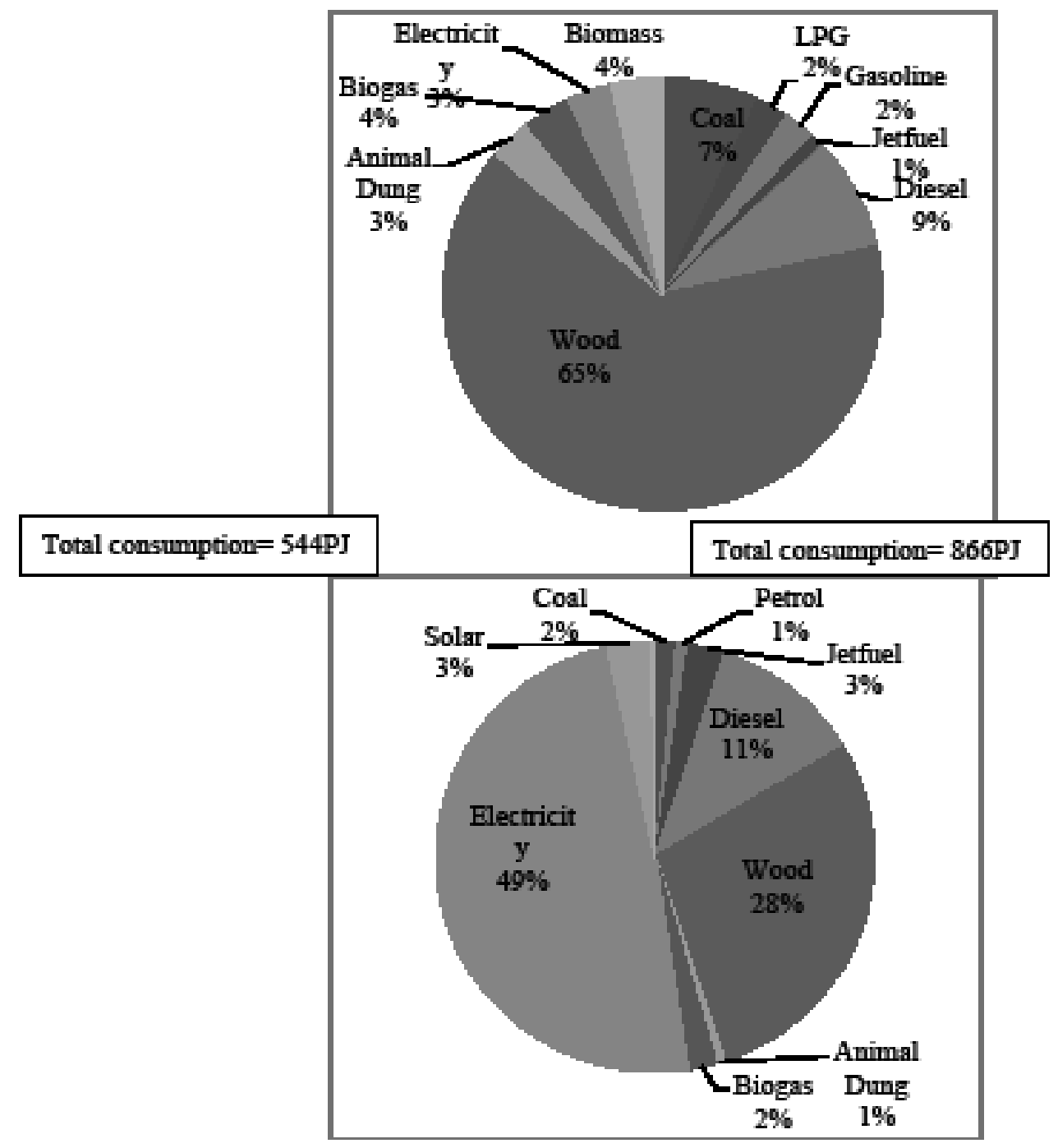

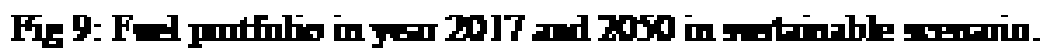

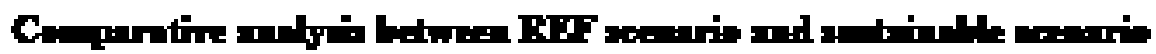

\section{i. Ferty induitis}

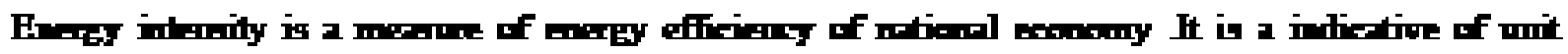

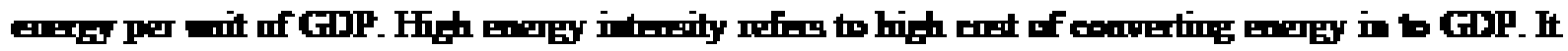

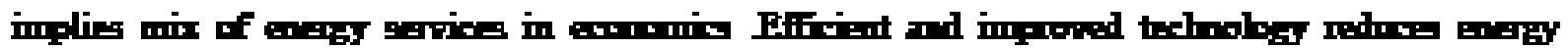

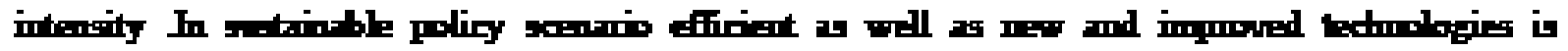

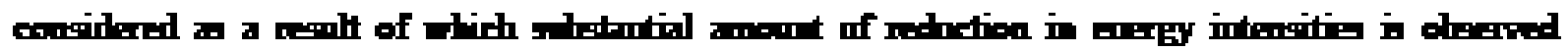

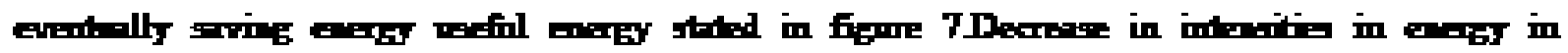

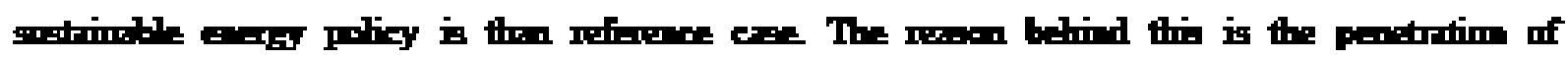

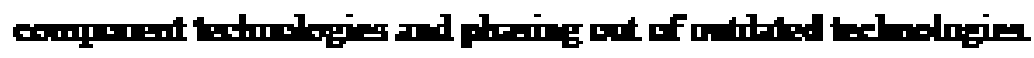




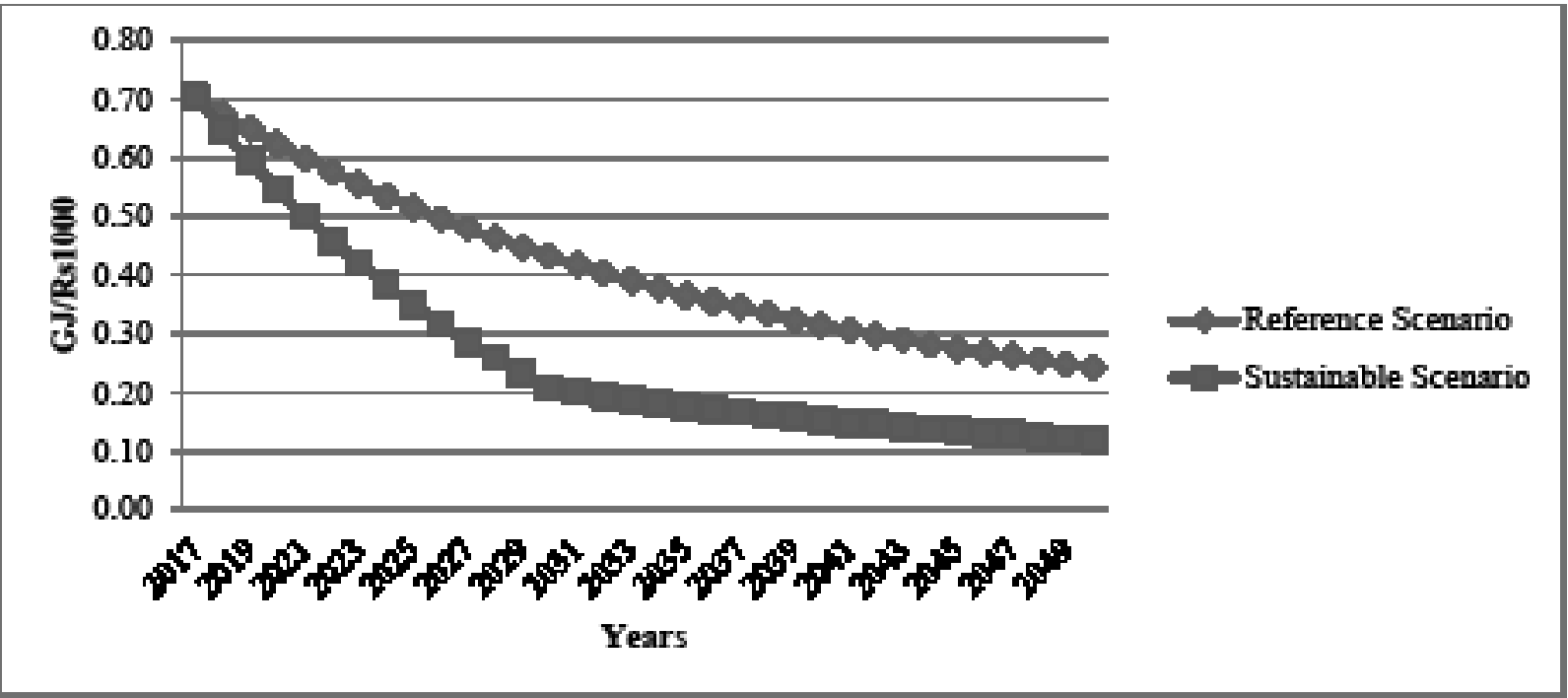

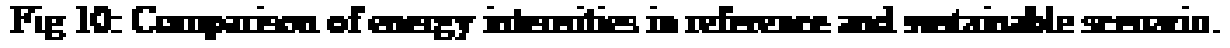

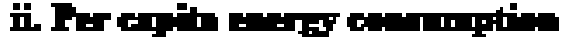

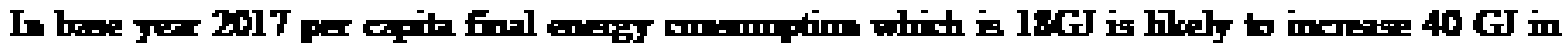

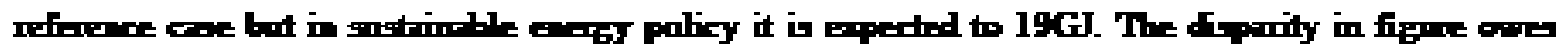

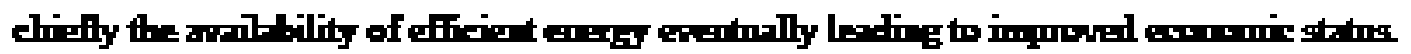

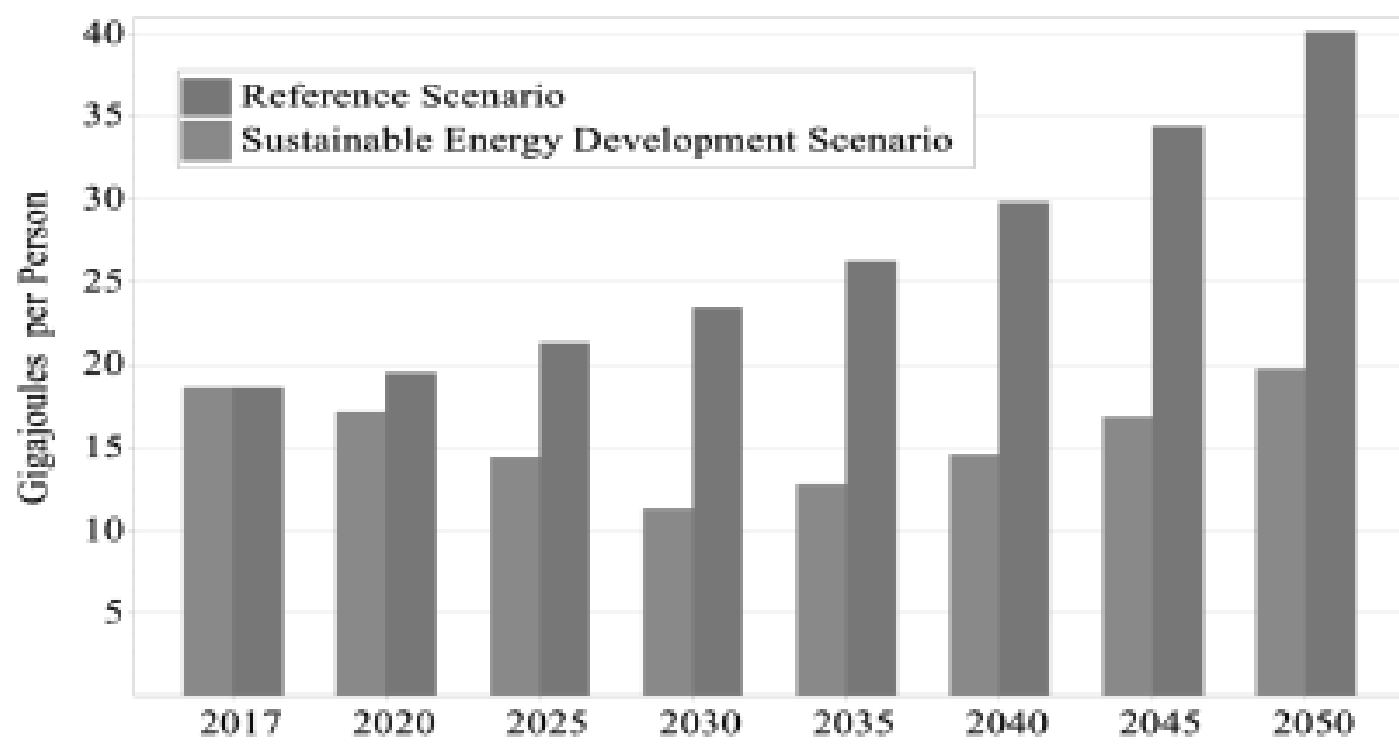

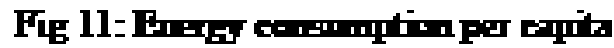

F-:.rim and Mitightim Putenti-l

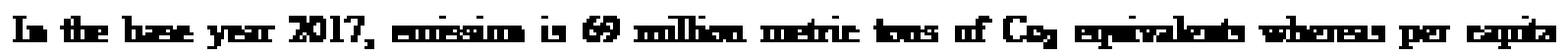

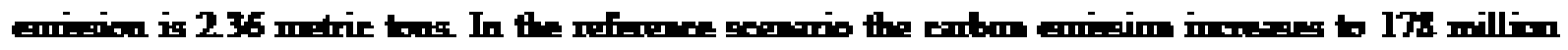

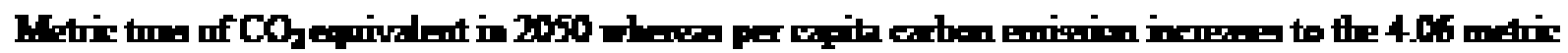

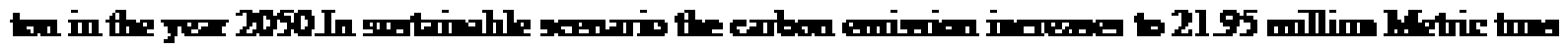

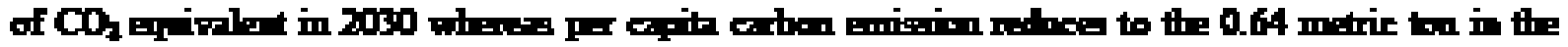
yer. 2030 doe to the tactimlogiesl policy intervention. 


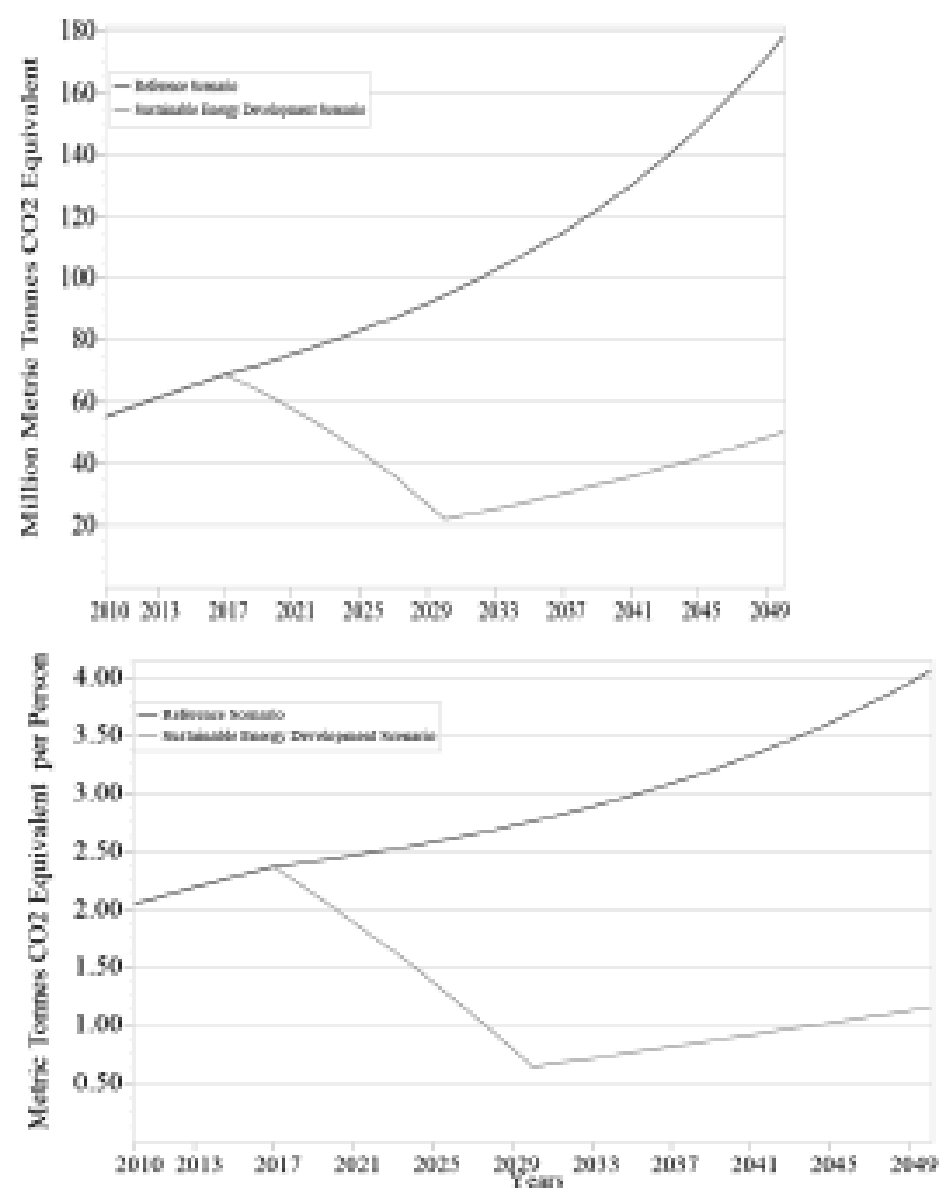

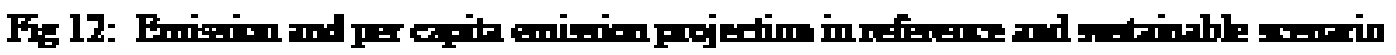

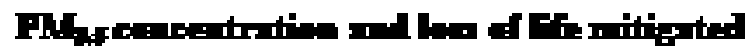

Fine particulate matter $\left(\mathrm{PM}_{2 \mathrm{~s}}\right)$ is an air pollutant that is a concern for people's health when levels in

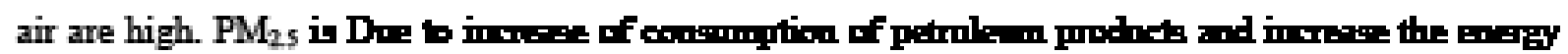

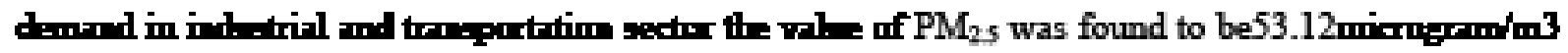
in bere yeir 2017 which may above WHO standard of 10 miengyomfm3 [24]. The figure shows that

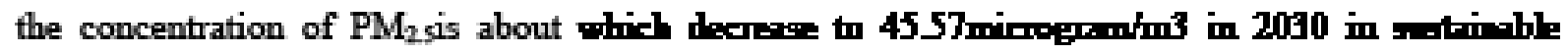
srewin. 


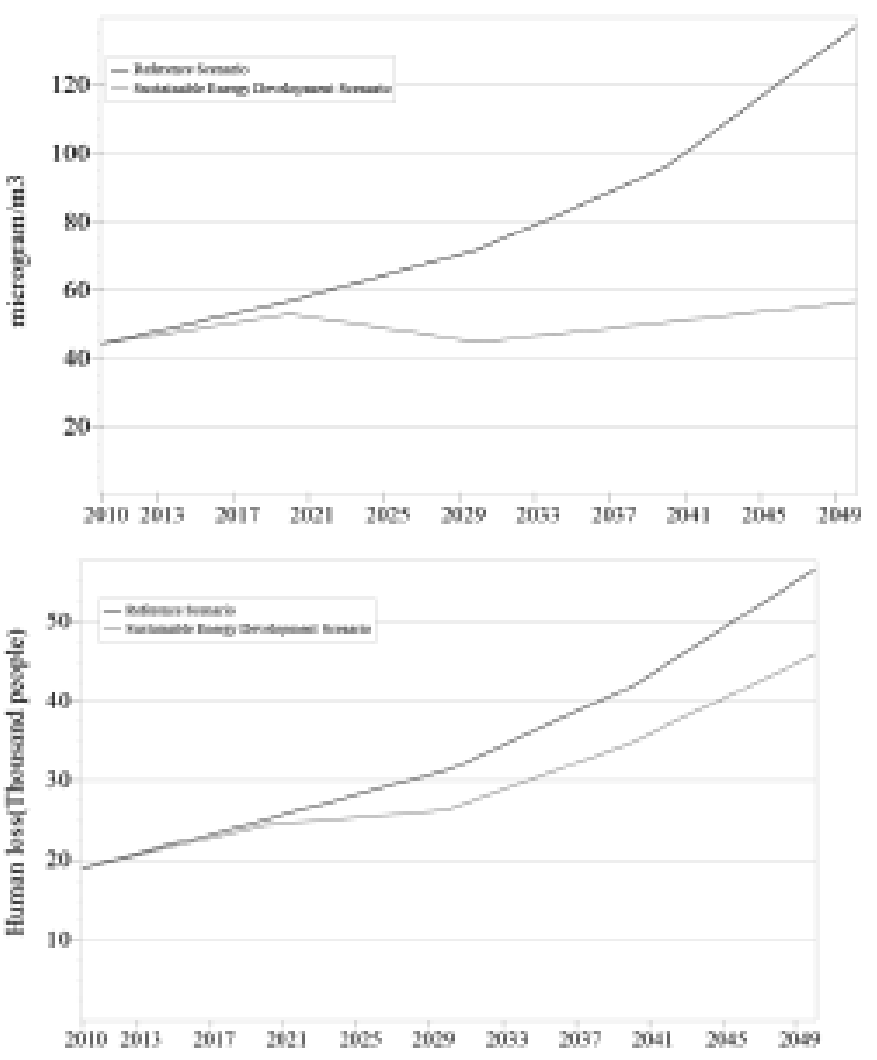

Fig 13: $\mathbf{P M}_{2 s}$ concentration and human loss projection in reference and sustainable scenario

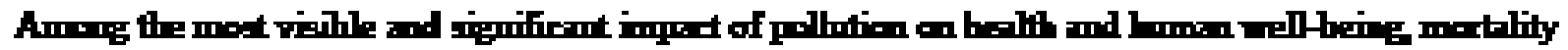

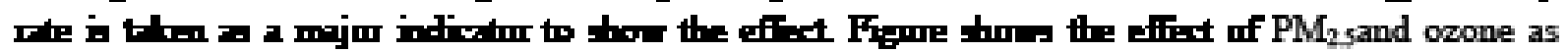
lives lost due to exposure to these pollutants.

Dee to inelene of enocestration vilne of $\mathrm{PM}_{25}$ and depletion of Ozone layer the number of loss of people is twenty two thousand at the base year 2017 Which is increase to 56 thousand people loss by 2050.

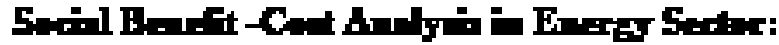

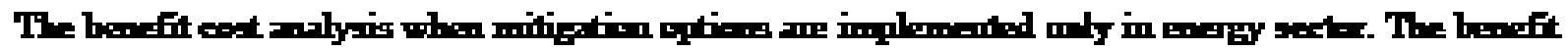

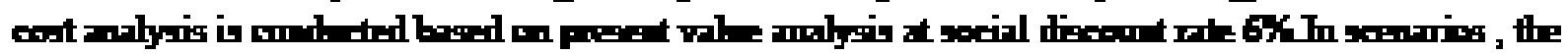

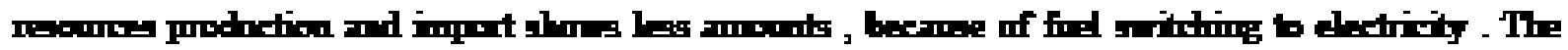

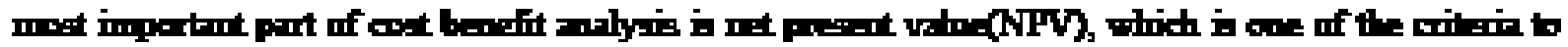

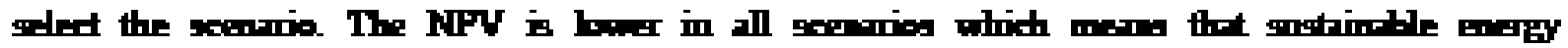

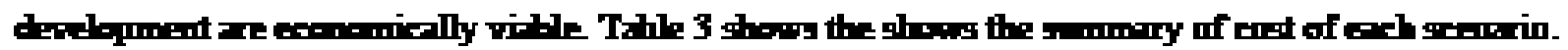

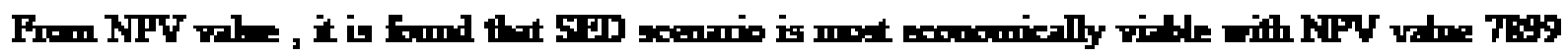
million NRS. 


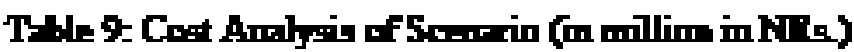

\begin{tabular}{|c|c|c|c|c|}
\hline Cumulative Costs \&\& Benefits & $\begin{array}{c}\text { Reference } \\
\text { Scenario }\end{array}$ & $\begin{array}{l}\text { Low } \\
\text { Economy } \\
\text { Scenario }\end{array}$ & $\begin{array}{l}\text { Sustainable Energy } \\
\text { Development } \\
\text { Scenario }\end{array}$ & $\begin{array}{l}\text { Accelerate } \\
\text { Economy } \\
\text { Scenario }\end{array}$ \\
\hline Demand & 894.3 & 801.4 & 939.6 & $1,027.7$ \\
\hline Reridntal & 567 & 5673 & 6563 & 5673 \\
\hline Intugtrial & B2.5 & 61.0 & 902 & 1121 \\
\hline Commeriel & 75.5 & 524 & 1221 & 109.6 \\
\hline Thengextativa & 37.1 & $\mathbf{2 9 . 0}$ & ]4.B & 47.5 \\
\hline Aprivituse & 1319 & 91.7 & 56.1 & 1913 \\
\hline Transformation & 280.2 & 231.7 & $1,667.4$ & 375.5 \\
\hline Thenchametion and Distributim & - & - & - & - \\
\hline GridElextricty & 265.0 & 216.5 & $1,594.6$ & 3600 \\
\hline OffGidenertrivity Genction & 153 & 152 & 728 & 15.5 \\
\hline Resources & $9,194.5$ & $8,234.4$ & $5,292.8$ & $10,540.6$ \\
\hline Podution & 6,0703 & $5,916.9$ & 3,7480 & 6,21R9.R \\
\hline Imports & 3,1242 & $2,317.5$ & $1,544.9$ & 4,2507 \\
\hline Epoxts & - & - & - & - \\
\hline Unmet Rey insments & - & - & - & - \\
\hline $\begin{array}{l}\text { Environmental Externalities } \\
\text { Non Energy Sector Costs }\end{array}$ & - & $\begin{array}{l}- \\
-\end{array}$ & - & - \\
\hline Net Present Value & $10,369.0$ & $9,267.4$ & $7,899.9$ & $11,943.8$ \\
\hline GHG Emisive (hill Than CODe) & $4,192.6$ & $3,765.6$ & 1,7627 & 4,at:B \\
\hline
\end{tabular}

\section{Condrian}

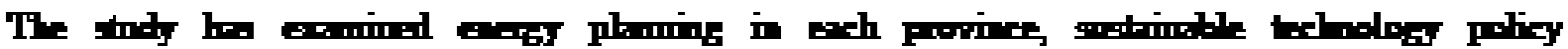

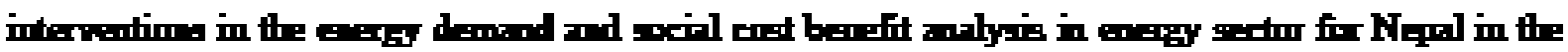

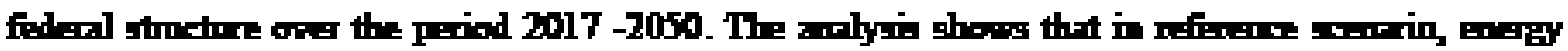

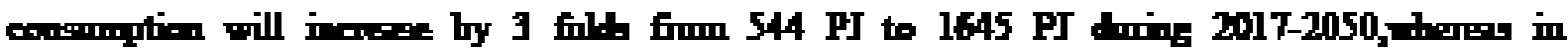

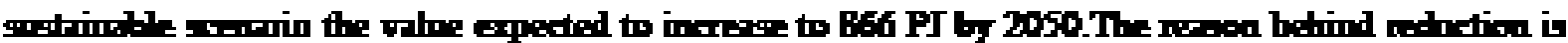




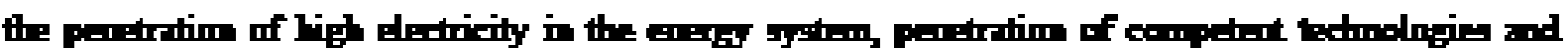

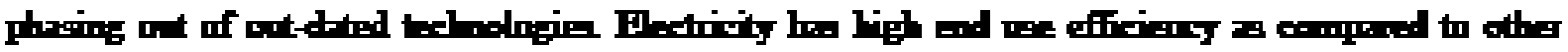

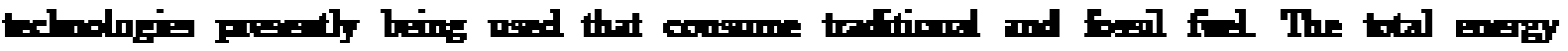

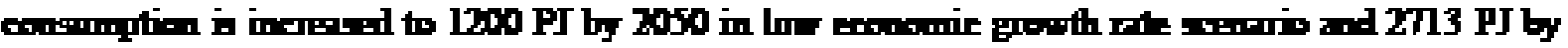

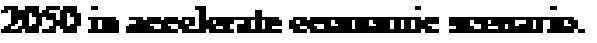

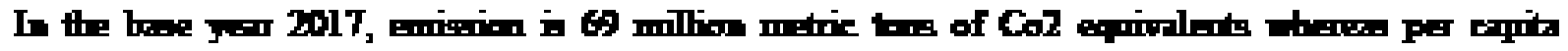

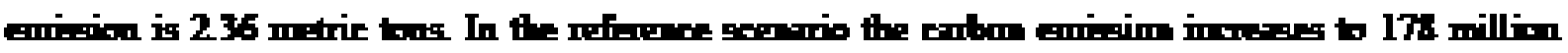

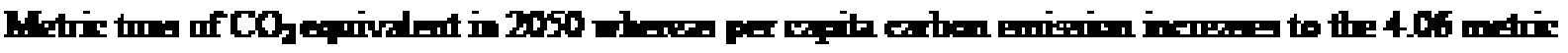

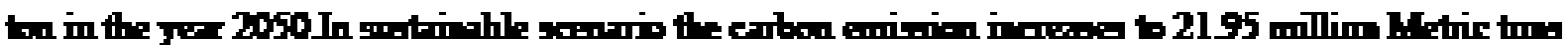

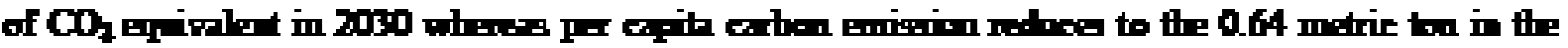
year 2030 due to the tatmologienlpolicy intervention.

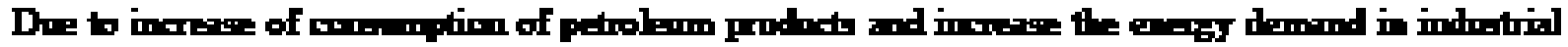

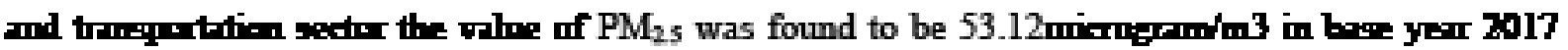

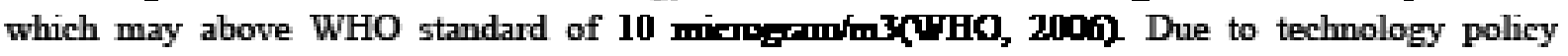

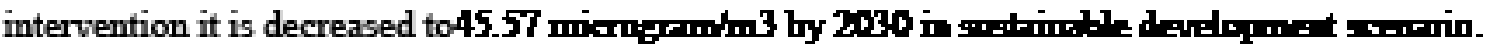

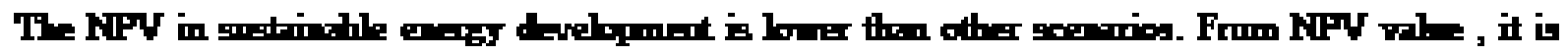

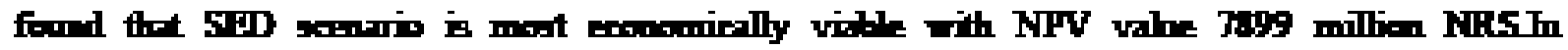

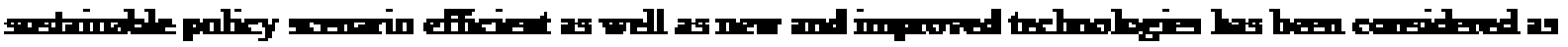

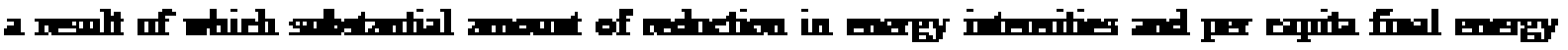

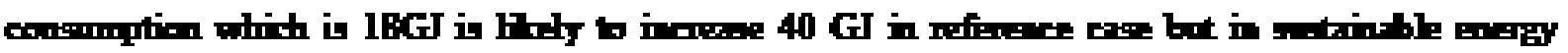

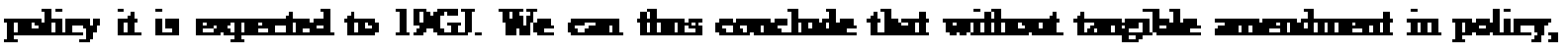

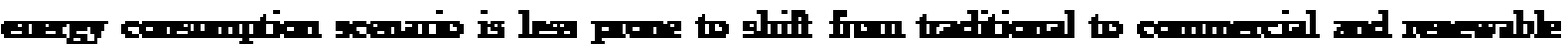

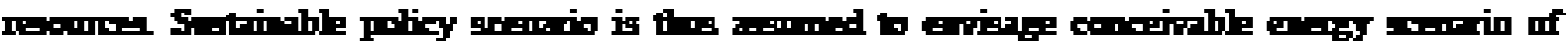

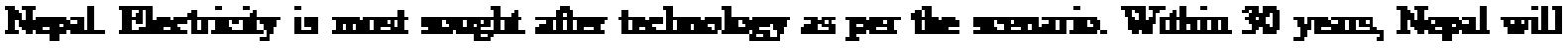

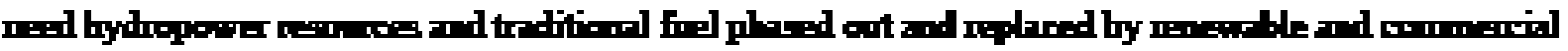

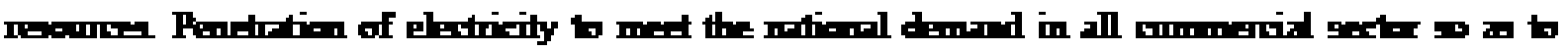

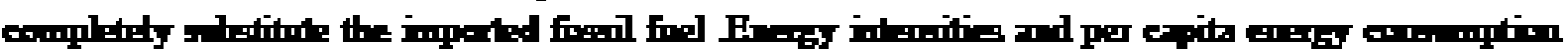

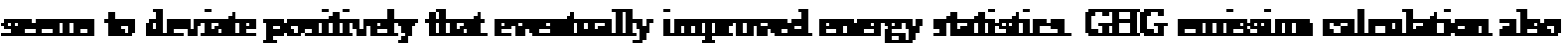

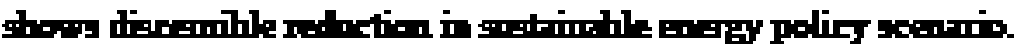

\section{Beferencex}

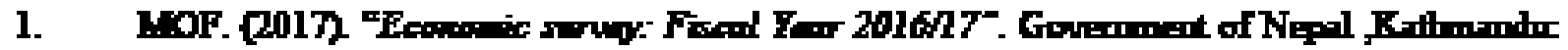
Minity of Fin.are.

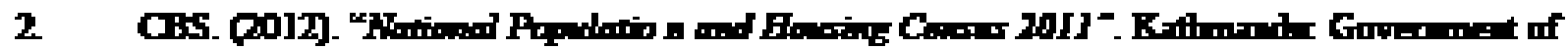

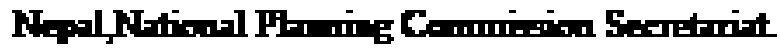

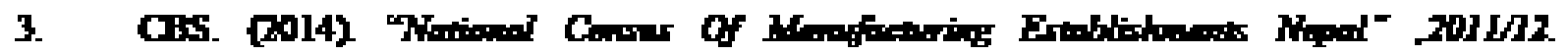

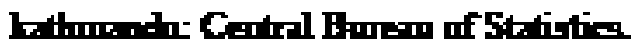

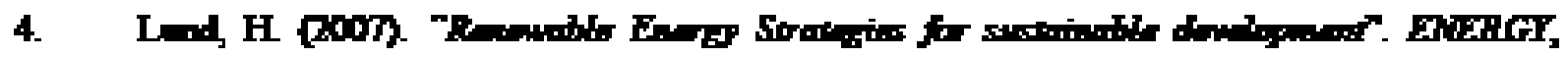
912-919.

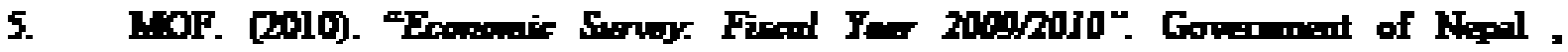

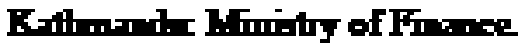

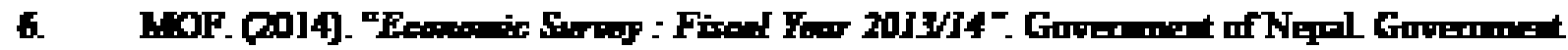
of Nopal , K-thmendr Minitry offinmm 


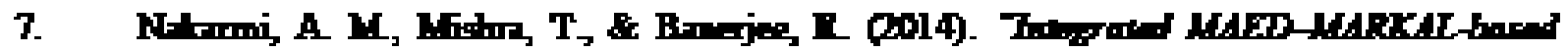

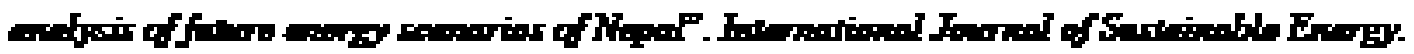

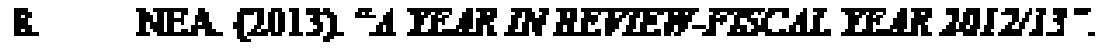

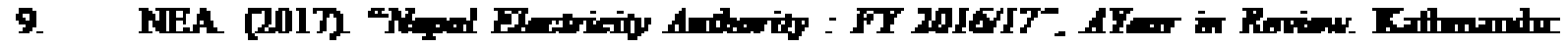
Nopal Electririty Anthrity.

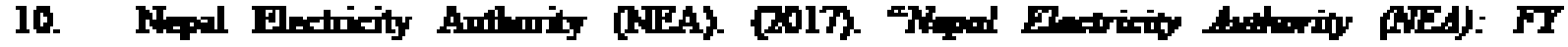
201617,A Yea i Revier, Koflemmin

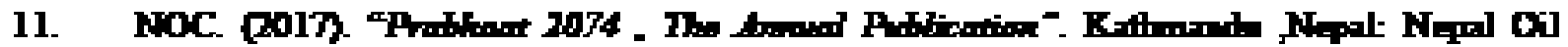
Comporatim

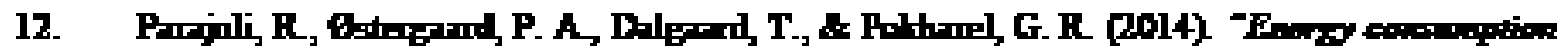

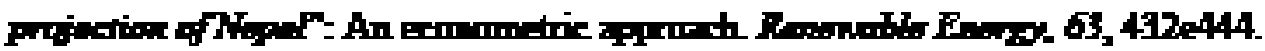

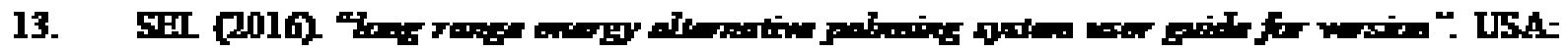

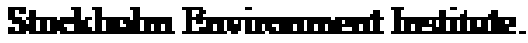

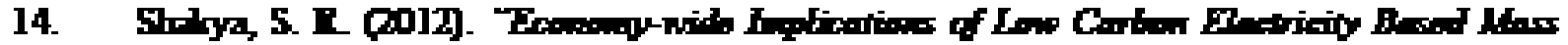

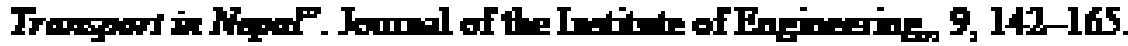

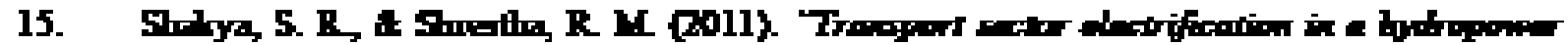

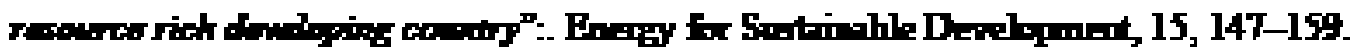

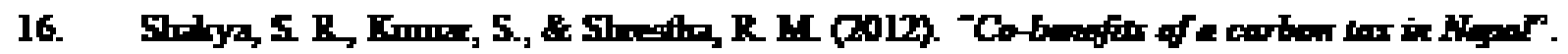

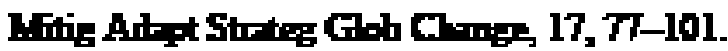

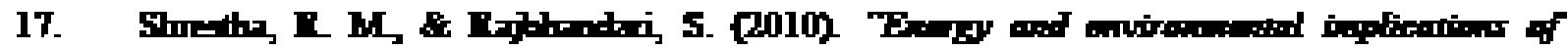

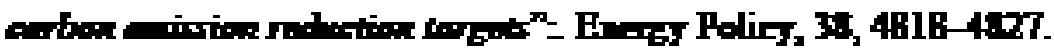

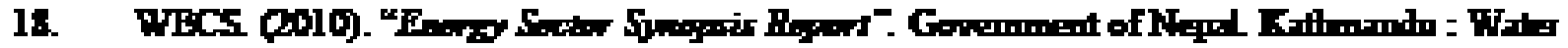
and Energy Comminion Sandrict

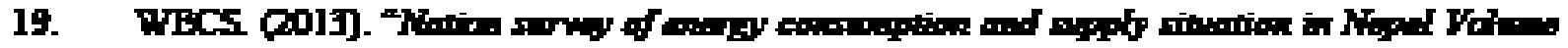

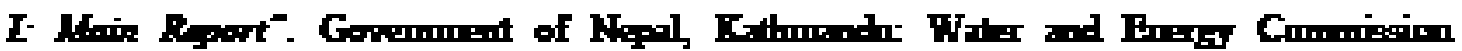
Seciltarivt

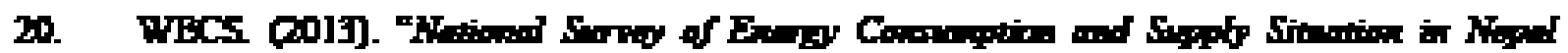

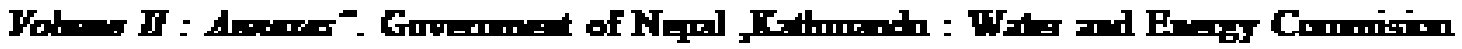
Secritaint

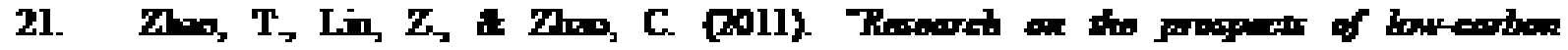

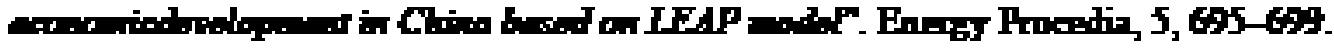

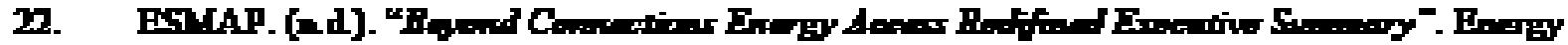

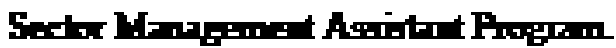

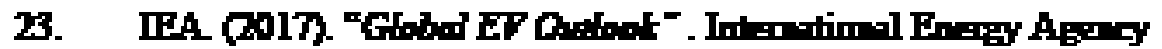

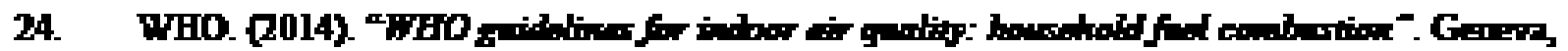

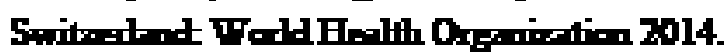

